\title{
Local Government Unit's Support to Educational Programs as Viewed by the Citizens: The Case of Lezo, Aklan
}

\section{Cecilia T. Reyes ${ }^{1}$ Cecile 0. Legaspi $^{2}$ Clyde G. Abayon ${ }^{3}$ Tomas O. Ortega $^{4}$ Anna Mae C. Relingo $^{5}$ Mary Eden M. Teruel ${ }^{6}$ Jyanee Loi D. Yecla ${ }^{7}$}

\author{
${ }^{1}$ School of Veterinary Medicine, Aklan State University, Philippines \\ ${ }^{2}$ School of Management Sciences, Aklan State University, Philippines \\ ${ }^{3}$ College of Agriculture Forestry and Environmental Sciences, Aklan State University, Philippines \\ ${ }^{4}$ School of Arts and Sciences, Aklan State University, Philippines \\ ${ }^{5}$ College of Agriculture Forestry and Environmental Sciences, Aklan State University, Philippines \\ ${ }^{6}$ School of Arts and Sciences, Aklan State University, Philippines \\ ${ }^{7}$ School of Arts and Sciences, Aklan State University, Philippines
}

\begin{abstract}
A study was conducted to evaluate the performance in the delivery of support to education programs of the Local Government Unit (LGU) of Lezo, Aklan. The samples were determined adopting the MultiStage Random Probability Sampling technique. The targeted 150 respondents were proportionately allocated in each barangay based on the 2015 Census Population and Housing Data from the Philippine Statistical Authority. The qualified sample respondents were selected using the Kish Grid. Female respondents were targeted for even numbered questionnaires while male respondents were targeted for odd numbers. The four major core concepts namely awareness, availment, satisfaction and need for action were used in measuring the rating of the respondents and presented in frequency and percentage distributions. The reasons for their response were likewise gathered. The study concluded that most of the respondents were not aware of scholarships and other assistance programs for students and alternative learning system and other special education programs. Low adjectival rating of citizens availment on educational programs was noted from the survey. This implies that there is a need for considerable improvement and significant interventions for the citizens to be knowledgeable and be able to avail those educational services offered in the Municipality of Lezo. In general, respondents were satisfied on educational programs. In spite of this positive feedback, additional efforts toward improvement are still essential. It is recommended that the LGU must provide budget for the construction of school buildings, libraries, and other facilities and acquisition of needed reference materials in order to provide its citizens with conducive environment for learning.
\end{abstract}

Keywords: Support to Education, Awareness, Availment, Satisfaction, Need for Action

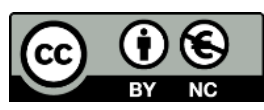

This is an open access article under the CC-BY-NC license

\section{INTRODUCTION}

The performance of the Local Government Unit of Lezo Aklan in the delivery of support to education programs was measured adopting the Citizens' Satisfaction Index System (CSIS). CSIS was designed as a system of mechanisms aimed to generate citizens' feedback on local government's performance on service delivery and the citizens' general satisfaction. The CSIS served as tool for drawing in applicable information in measuring citizen satisfaction that can be utilized for agenda-setting of economic and human development plans and goals of LGU's. Moreover, it is a source of information that identifies strengths, gaps, difficulties, constraints and 
possible improvements on the on the delivery of quality health services. By virtue of DILG Memorandum Circular 2016-57, the CSIS was pilot tested to 31 municipalities in the country to equip the tools and procedures for wider implementation in the succeeding years. Local resource institutes are involved to gather data and interpret the results for research and development purposes.

As a feedback mechanism, the citizens, being the intended recipients and end-users of public services, are in the best position to determine whether or not the services are delivered according to their needs and to the extent that they fulfil their day-to-day and long-term human development requirements. Through CSIS, the gathering of their sentiments, opinions and insights according to their perceptions and assessment as consumers of local public services is a logical method of shaping what the local governments need to do to ensure welfare of citizens, without neglect to statutory requirements expected from them. The CSIS have numerous uses for various stakeholders pursuing relevant contribution to attain socio-economic development goals both in the local and national arena.

Statement of the Problem

This study was conducted to evaluate the performance of Local Government Unit of Lezo, Aklan in the delivery of support to education programs. Specifically, this study aimed to answer the following questions:

1. What is the profile of the respondents as to

a. whether or not the respondents have household members studying in an elementary or high school,

b. the grade level of respondents' household members who are studying during the past 12 months and at present,

c. whether the respondents' have household members studying in public or private schools, and

d. the primary reason why the respondents' household members studied in public schools?

2. What is the respondent's rating and its reasons in the delivery of the following support to education services:

a. provision of medical and/or nutritional services to school clinics,

b. sports programs and services,

c. scholarships and other assistance programs for students, and

d. alternative learning system (ALS) and/or other special education programs?

3. What are the recommendations from citizens on support to education programs?

\section{RESEARCH METHOD}

The Respondents. The target respondents of the study were 150 voting age adults (18 years and above) residing in the different barangays of Lezo for not less than six months. The greatest number of respondents (20) came from barangay Poblacion since it is the most populated barangay. Four sample spots were generated from this barangay. Fifteen respondents each from barangays Agcawilan, Carugdog, Ibao, Tayhawan, and ten respondents each from barangays Bagto, Bugasongan, Cogon, Mina, Santa Cruz, Santa Cruz Bigaa, and Silakat-Nonok.

Sampling Procedures. The town of Lezo, Aklan has a total population of 15,224 and it is impossible to interview everyone, thus, multi-stage random probability sampling was utilized to come up with 150 sample-respondents. Multi-stage random probability sampling uses several stages or phases in getting the sample at random from the population. This method is an extension or a multiple application of the stratified random sampling technique. The following stages were done in sampling: 
International Journal of Emerging Issues in Early Childhood Education (IJEIECE), Vol. 3 (1), Page 35-43

Local Government Unit's Support to Educational Programs as Viewed by the Citizens: The Case of Lezo,

Aklan

C. T. Reyes, C. O. Legaspi, C. G. Abayon, T. O. Ortega, A. M. C. Relingo, M. E. M. Teruel, J. L. D Yecla

Stage 1 . The targeted 150 respondents were proportionately allocated in each barangay based on the 2015 Census Population and Housing data from the Philippine Statistical Authority. In each barangay, 30 sample spots such as church/chapel, school, health center and/or radio station were identified.

Stage 2. Sample households in each sample spot were selected by determining the sample spot which was the starting point. From the sample spot going to the right, the first sample household was determined by counting as many households as indicated by the random start (RS). After the first household was identified, an interval using the number indicated in the random start was made to select the other households.

Stage 3. Qualified sample respondent in each household was selected using the Kish Grid. Female respondents were targeted for even numbered questionnaires while male respondents were targeted for odd numbers.

Data analysis. The core concepts in measuring the responses of the respondents using the frequency and percentage distribution are as follows:

1. Awareness refers to the respondent's presence of knowledge to the service being offered by the local government unit. Before delving with satisfaction, there is a need in the first place to know if they are aware that the service is being provided by their local government unit.

2. Availment refers to the contact of the respondent to local government through programs, projects and services being implemented or offered. This may suggest the demand or utilization of public services by the citizens. For service indicator level assessments, only those who said they were aware of the service will be asked with the availment questions.

3. Satisfaction refers to the citizen's contentment with their experience in availing or contact with the local government's services. In some cases this can also reflect the citizen's fulfilment of expectations with the services they were able to experience. For service indicator level assessments, only those who have availed of the particular service are asked with the satisfaction question. On the service area level, satisfaction is gathered regardless of their awareness and availment of any of the service indicators.

4. Need for Action refers to the citizen's assessment on whether or not a particular service requires specific and decisive actions for improvement or reform. This concept is paired with satisfaction to provide readers an additional dimension that could help refine prioritization of services for further development and reform.

\section{RESULTS AND DISCUSSIONS}

1. Profile of Respondents with Household Members in Public Schools

a. Response as to Whether or Not the Respondents' Have Household Members Studying in an Elementary or High School

Table 1.

Response as to Whether or Not the Respondents' Have Household Members Studying in an Elementary or High School

\begin{tabular}{lcc}
\hline Response & Frequency $(\mathbf{n}=\mathbf{1 5 0})$ & Percent \\
\hline Yes & 74 & 49.33 \\
No & 76 & 50.67 \\
\hline
\end{tabular}


International Journal of Emerging Issues in Early Childhood Education (IJEIECE), Vol. 3 (1), Page: 35-43

Local Government Unit's Support to Educational Programs as Viewed by the Citizens: The Case of Lezo,

Aklan

C. T. Reyes, C. O. Legaspi, C. G. Abayon, T. O. Ortega, A. M. C. Relingo, M. E. M. Teruel, J. L. D Yecla

Table 1 shows the response as to whether or not the respondents' have household members studying in an elementary or high school. It can be drawn from the results that almost half (74 or $49.33 \%$ ) of the total number of the respondents indicated that they have household members studying in either elementary or high school. On the other hand, seventy-six or $50.67 \%$ of the respondents stated that they have no household member studying in either elementary or high school.

b. Grade Level of Respondents' Household Members Who Are Studying During the Past 12 Months and at Present

Table 2.

Grade Level of Respondents' Household Members Who Are Studying During the Past 12 Months and at Present

\begin{tabular}{lcc}
\hline \multicolumn{1}{c}{ Indicator } & Frequency $(\mathbf{n}=\mathbf{1 3 6})$ & Percent \\
\hline Kindergarten & 7 & 5.15 \\
Grade 1 & 13 & 9.56 \\
Grade 2 & 9 & 6.62 \\
Grade 3 & 8 & 5.88 \\
Grade 4 & 8 & 5.88 \\
Grade 5 & 9 & 6.62 \\
Grade 6 & 9 & 6.62 \\
Grade 7 & 9 & 6.62 \\
Grade 8 & 13 & 9.56 \\
Grade 9 & 19 & 13.97 \\
Grade 10 & 1 & 0.74 \\
Grade 11 & 16 & 11.76 \\
Grade 12 & 15 & 11.03 \\
\hline
\end{tabular}

Table 2 shows the grade level of respondents' household members who are studying during the past 12 months and at present. The result shows that most (19 or $13.97 \%$ ) of the respondents' household members who are studying were in Grade 9. This number is closely followed by the respondents' household members who are in Grade 11 (16 or $11.76 \%)$ and Grade $12(11.03 \%)$.

c. Response as to Whether the Respondents' Have Household Members Studying in Public or Private Schools.

Table 3.

Response as to Whether the Respondents' Have Household Members Studying in Public or Private Schools

\begin{tabular}{lcc}
\hline \multicolumn{1}{c}{ Indicator } & Frequency $(\mathbf{n}=\mathbf{1 3 6})$ & Percent \\
\hline Public & 113 & 83.09 \\
Private & 23 & 16.91 \\
\hline
\end{tabular}

Table 3 presents the response as to whether the respondents' have household members studying in public or private schools. It can be drawn from the results that large proportion (113 or $83.09 \%$ ) of the respondents has household members studying in public or private schools while only 
International Journal of Emerging Issues in Early Childhood Education (IJEIECE), Vol. 3 (1), Page 35-43

Local Government Unit's Support to Educational Programs as Viewed by the Citizens: The Case of Lezo,

Aklan

C. T. Reyes, C. O. Legaspi, C. G. Abayon, T. O. Ortega, A. M. C. Relingo, M. E. M. Teruel, J. L. D Yecla

twenty-three or $16.91 \%$ of the respondents have no household members

studying in either public or private schools.

d. Primary Reason Why the Respondents' Household Members Studied in Public Schools

Table 4.

Primary Reason Why the Respondents' Household Members Studied in Public Schools

\begin{tabular}{|c|c|c|}
\hline Indicator & $\begin{array}{c}\text { Frequency } \\
(\mathrm{n}=113)\end{array}$ & Percent \\
\hline Libre ang tuition (Free tuition) & 34 & 30.09 \\
\hline Mababa ang tuition (Affordable tuition) & 23 & 20.35 \\
\hline $\begin{array}{l}\text { Maganda ang kalidad ng pagtuturo (Good quality } \\
\text { of teaching) }\end{array}$ & 4 & 3.54 \\
\hline $\begin{array}{l}\text { Sapat/Maayos ang mga pasilidad ng paaralan } \\
\text { (Adequate school facilities) }\end{array}$ & 1 & 0.88 \\
\hline $\begin{array}{l}\text { Maganda ang pangangasiwa ng paaralan (Good } \\
\text { school administration) }\end{array}$ & 5 & 4.42 \\
\hline $\begin{array}{l}\text { Libre ang mga kagamitan tulad ng libro at iba pang } \\
\text { pangangailangan ng mag-aaral (School supplies } \\
\text { and other learning materials are given free) }\end{array}$ & 1 & 0.88 \\
\hline $\begin{array}{l}\text { Malapit ang paaralan sa aming tirahan (The } \\
\text { location is near) }\end{array}$ & 44 & 38.94 \\
\hline $\begin{array}{l}\text { Parehas lang ang tinuturo sa private school (Same } \\
\text { learning contents with the private school) }\end{array}$ & 1 & 0.88 \\
\hline
\end{tabular}

Table 4 reflects the primary reason why the respondents' household members studied in public school. It is reflected in the results that most (44 or 38.94\%) of the respondents' household members studied in public school because the school is near. This is closely followed by the number of the respondents (30.09\%) who provided the reason that the tuition is free. Moreover, least number (1 or $0.88 \%$ ) cited the reason of good facilities, free school supplies, and instruction is just the same with the private schools, respectively.

2. Extent of awareness, availment, satisfaction and need for action of the following support to education programs:

a. Provision of Medical and/or Nutritional Services to School Clinics

Table 5.

Percentage Scores and Adjectival Ratings of the Major Core Concepts on Provision of Medical and/or Nutritional Services to School Clinics

\begin{tabular}{|c|c|c|c|c|c|c|}
\hline \multirow{2}{*}{$\begin{array}{c}\text { Core } \\
\text { Concepts }\end{array}$} & \multicolumn{2}{|c|}{ Yes } & \multicolumn{2}{|c|}{ No } & \multirow{2}{*}{$\begin{array}{c}\text { Percentage } \\
\text { Score }\end{array}$} & \multirow{2}{*}{$\begin{array}{c}\text { Adjectival } \\
\text { Rating }\end{array}$} \\
\hline & $\mathrm{F}$ & $\%$ & $\mathrm{~F}$ & $\%$ & & \\
\hline Awareness & 104 & 69.33 & 46 & 30.67 & $69.33 \%$ & High \\
\hline Availment & 54 & 51.92 & 50 & 48.08 & $51.92 \%$ & Low \\
\hline Satisfaction & 48 & 88.89 & 6 & 11.11 & 88.89 & High \\
\hline $\begin{array}{l}\text { Need for } \\
\text { Action }\end{array}$ & 15 & 27.78 & 39 & 72.22 & $27.78 \%$ & Low \\
\hline
\end{tabular}

Awareness. Table 5 presents awareness on the provision of medical and/or nutritional services to school clinics. The result shows that majority (104 or $69.33 \%$ ) of the respondents were aware of the services while forty-six or $30.67 \%$ indicated of having no idea about the said service. 
International Journal of Emerging Issues in Early Childhood Education (IJEIECE), Vol. 3 (1), Page: 35-43

Local Government Unit's Support to Educational Programs as Viewed by the Citizens: The Case of Lezo,

Aklan

C. T. Reyes, C. O. Legaspi, C. G. Abayon, T. O. Ortega, A. M. C. Relingo, M. E. M. Teruel, J. L. D Yecla

Availment. The availment on the provision of medical and/or nutritional services to school clinics is shown in Table 5. The result displays that fifty-four or $51.92 \%$ of the respondents availed the services while fifty or $48.08 \%$ stated they have not availed of any of the medical and/or nutritional services.

Satisfaction. Table 5 also displays satisfaction on the provision of medical and/or nutritional services to school clinics. The result exhibits that out of the fifty-four (54) respondents who availed the medical services, forty-eight or $88.89 \%$ percent noted that they were satisfied while six or $11.11 \%$ indicated they were not satisfied of the services.

Need for Action. The need for action on the provision of medical and/or nutritional services to school clinics is also shown in Table 5. The result shows that out of the fifty-four (54) respondents who availed the medical services, fifteen or $27.78 \%$ noted that the services need action while thirty-nine or $72.22 \%$ specified that the services do not need action.

b. Sports Programs and Activities

Table 6.

Percentage Scores and Adjectival Ratings of the Major Core Concepts on Sports programs and activities

\begin{tabular}{ccccccc}
\hline $\begin{array}{c}\text { Core } \\
\text { Concepts }\end{array}$ & F & $\%$ & F & $\%$ & Nescentage & $\begin{array}{c}\text { Adjectival } \\
\text { Score }\end{array}$ \\
Rating \\
\hline Awareness & 89 & 59.33 & 61 & 40.67 & $\mathbf{5 9 . 3 3 \%}$ & High \\
Availment & 39 & 43.82 & 50 & 56.18 & $\mathbf{4 3 . 8 2 \%}$ & Low \\
Satisfaction & 38 & 97.44 & 1 & 2.56 & $\mathbf{9 7 . 4 4 \%}$ & High \\
$\begin{array}{c}\text { Need for } \\
\text { Action }\end{array}$ & 10 & 25.64 & 29 & 74.36 & $\mathbf{2 5 . 6 4 \%}$ & Low \\
\hline
\end{tabular}

Awareness. Table 6 presents awareness on sports programs and activities. The result indicates that majority ( 89 or $59.33 \%$ ) respondents were aware of the sports programs and activities while sixty-one or $40.67 \%$ said that they were not aware of the services.

Availment. The availment of sports programs and activities is reflected in Table 6 . The result shows that out of eighty-nine (89) respondents who were aware of the sports programs and activities, majority (50 or $56.18 \%$ ) of them did not avail the services while only thirty-nine or $43.82 \%$ availed the services.

Satisfaction. Table 6 also displays satisfaction on the sports programs and activities. The result shows that out of thirty-nine (39) respondents who availed the sports programs and activities, highest proportion (38 or 97.44\%) of the respondents were satisfied of the services while only one or $2.56 \%$ indicated dissatisfaction of the service.

Need for Action. The need for action on the sports programs and activities is also presented in Table 6. It can be drawn from the results that out of thirty-nine (39) respondents who availed the sports programs and activities, twenty-nine or $74.36 \%$ of the respondents noted that the services do not need action while ten or $25.64 \%$ stated that the services need action. 
International Journal of Emerging Issues in Early Childhood Education (IJEIECE), Vol. 3 (1), Page 35-43

Local Government Unit's Support to Educational Programs as Viewed by the Citizens: The Case of Lezo,

Aklan

C. T. Reyes, C. O. Legaspi, C. G. Abayon, T. O. Ortega, A. M. C. Relingo, M. E. M. Teruel, J. L. D Yecla

c. Scholarships and Other Assistance Programs for Students

Table 7.

Percentage Scores and Adjectival Ratings of the Major Core Concepts on Scholarships and Other Assistance Programs for Students

\begin{tabular}{|c|c|c|c|c|c|c|}
\hline \multirow{2}{*}{$\begin{array}{c}\text { Core } \\
\text { Concepts }\end{array}$} & \multicolumn{2}{|c|}{ Yes } & \multicolumn{2}{|c|}{ No } & \multirow{2}{*}{$\begin{array}{c}\text { Percentage } \\
\text { Score }\end{array}$} & \multirow{2}{*}{$\begin{array}{c}\text { Adjectival } \\
\text { Rating }\end{array}$} \\
\hline & $\mathrm{F}$ & $\%$ & $\mathrm{~F}$ & $\%$ & & \\
\hline Awareness & 84 & 56.00 & 66 & 44.00 & $56 \%$ & Low \\
\hline Availment & 21 & 25.00 & 63 & 75.00 & $25 \%$ & Low \\
\hline Satisfaction & 21 & 100.00 & 0 & 0 & $100 \%$ & High \\
\hline $\begin{array}{l}\text { Need for } \\
\text { Action }\end{array}$ & 8 & 38.10 & 13 & 61.90 & $38.10 \%$ & Low \\
\hline
\end{tabular}

Awareness. Table 7 presents awareness on scholarships and other assistance programs for students. The result shows that majority ( 84 or 56\%) of the respondents were aware of scholarships and other assistance programs for students while sixty-six or $44 \%$ of the respondents stated that they were not aware of the said services.

Availment. Table 7 shows availment on scholarships and other assistance programs for students. The result reflects that out of eighty-four (84) respondents who were aware of the said services, only twenty-one or $25 \%$ of them availed while majority (63 or $75 \%$ ) did not avail the services.

Satisfaction. Table 7 also presents satisfaction on scholarships and other assistance programs for students. The result indicates that all (21) of the respondents who availed the said services noted that they were satisfied of the service.

Need for Action. The need for action on scholarships and other assistance programs for students is also presented in Table 7. The result shows that out of twenty-one (21) respondents who availed scholarships and other assistance programs for students, 13 or $61.90 \%$ of the respondents noted that the services do not need action while lesser proportion (8 or $38.10 \%$ ) stated that the services still need action.

d. Alternative Learning System and/or Other Special Education Programs

Table 8.

Percentage Scores and Adjectival Ratings of the Major Core Concepts on Alternative Learning System and/or other Special Education Programs

\begin{tabular}{|c|c|c|c|c|c|c|}
\hline \multirow{2}{*}{$\begin{array}{c}\text { Core } \\
\text { Concepts }\end{array}$} & \multicolumn{2}{|c|}{ Yes } & \multicolumn{2}{|c|}{ No } & \multirow{2}{*}{$\begin{array}{l}\text { Percentage } \\
\text { Score }\end{array}$} & \multirow{2}{*}{$\begin{array}{c}\text { Adjectival } \\
\text { Rating }\end{array}$} \\
\hline & $\mathrm{F}$ & $\%$ & $\mathrm{~F}$ & $\%$ & & \\
\hline Awareness & 62 & 41.33 & 88 & 58.67 & $41.33 \%$ & Low \\
\hline Availment & 2 & 3.23 & 60 & 96.77 & $3.23 \%$ & Low \\
\hline Satisfaction & 2 & 100.00 & 0 & 0 & $100 \%$ & High \\
\hline $\begin{array}{l}\text { Need for } \\
\text { Action }\end{array}$ & 1 & 50.00 & 1 & 50.00 & $50 \%$ & Low \\
\hline
\end{tabular}

Awareness. Table 8 presents awareness on Alternative Learning System and/or other Special Education Programs. The result shows that majority (88 or 58.67\%) of the respondents were not aware of the Alternative Learning System and/or other Special Education Programs while lesser number $(62$ or $41.33 \%$ of the respondents indicated that they were not aware of the said services.

Availment. Table 8 shows the availment on Alternative Learning System and/or other Special Education Programs. The result reflects that out of sixty-two (62) 
respondents who were aware of the said services, only two or $3.23 \%$ of them availed while the higher proportion ( 60 or $96.77 \%$ ) did not avail the services.

Satisfaction. Table 8 displays satisfaction on Alternative Learning System and/or other Special Education Programs. The result indicates that all (2) of the respondents who availed the services indicated that they were satisfied of the service.

Need for Action. Table 8 presents the need for action on Alternative Learning System and/or other Special Education Programs. The result shows that out of the two (2) respondents who availed Alternative Learning System and/or other Special Education Programs, one (1) respondent indicated that the services do not need action while the other one (1) stated that the services still need action.

Recommendations from Citizens

The overall recommendations from the citizens on support to education programs revealed that 71 or $47.33 \%$ out of the 150 respondents suggested that additional supply of books, computer and other educational materials be provided. This was followed by 15 or $10.0 \%$ of the respondents who recommended additional budget. Another, 14 or $9.33 \%$ suggested additional classrooms, and 9 or $6.0 \%$ of the respondents strongly recommended the implementation of free tuition in the tertiary education. The complete list of recommendations from citizens on support to education programs is shown on Table 9.

Table 9.

Recommendations from Citizens on Support to Education Programs

\begin{tabular}{|c|c|c|}
\hline Recommendations & $\begin{array}{c}\text { Frequency }(n= \\
150)\end{array}$ & Percent \\
\hline $\begin{array}{l}\text { Additional supply of books, } \\
\text { computer and other educational } \\
\text { materials }\end{array}$ & 71 & 47.33 \\
\hline Additional budget & 15 & 10.00 \\
\hline Additional classrooms & 14 & 9.33 \\
\hline Strongly implement free tuition & 9 & 6.00 \\
\hline Sustain implemented programs & 8 & 5.33 \\
\hline Provision of scholarship programs & 6 & 4.00 \\
\hline $\begin{array}{l}\text { Repair school buildings and } \\
\text { classrooms }\end{array}$ & 6 & 4.00 \\
\hline Improve program implementation & 5 & 3.33 \\
\hline $\begin{array}{l}\text { Improve information } \\
\text { dissemination }\end{array}$ & 3 & 2.00 \\
\hline Financial support for students & 2 & 1.33 \\
\hline Hire more teachers and staffs & 2 & 1.33 \\
\hline Additional programs & 1 & 0.67 \\
\hline $\begin{array}{l}\text { Addition fund allocation for MOOE } \\
\text { for classroom construction }\end{array}$ & 1 & 0.67 \\
\hline Improve school clinics & 1 & 0.67 \\
\hline Hire qualified teachers & 1 & 0.67 \\
\hline Seminars to educate youth & 1 & 0.67 \\
\hline $\begin{array}{l}\text { Seminars to enhance teachers' } \\
\text { knowledge and skills }\end{array}$ & 1 & 0.67 \\
\hline
\end{tabular}


International Journal of Emerging Issues in Early Childhood Education (IJEIECE), Vol. 3 (1), Page 35-43

Local Government Unit's Support to Educational Programs as Viewed by the Citizens: The Case of Lezo,

Aklan

C. T. Reyes, C. O. Legaspi, C. G. Abayon, T. O. Ortega, A. M. C. Relingo, M. E. M. Teruel, J. L. D Yecla

The LGU must look for agencies

that can provide budget to support $\quad 1 \quad 0.67$

the programs for education.

Revive ALS Program $\quad 1 \quad 0.67$

Rules must be strictly implemented $\quad 1 \quad 0.67$

\section{CONCLUSION}

The overall satisfaction rating for educational program is high. This means that the citizens' satisfaction with the local government's education related programs and services exhibits desired satisfactory performance. In spite of this positive feedback, additional efforts toward improvement are still essential. Lezo should toughen interventions for educational assistance such as scholarships and Alternative Learning System to further generate good feedbacks from the citizens.

Low adjectival rating of citizens' availment on educational programs was noted from the survey. The result on awareness also suggests that scholarships and other assistance programs and alternative learning system and/or special education programs have low adjectival ratings. These imply that there is a need for considerable improvement and significant interventions for the citizens to be knowledgeable and be able to avail those educational services offered in the Municipality of Lezo.

The adjectival rating of the citizens' satisfaction on educational program is high. Therefore, the Municipality of Lezo generally exhibits satisfactory performance. On-going interventions to sustain or even further improve the services are necessary to maintain the quality of service they offer to the public.

\section{RECOMMENDATION}

One important concern in public education programs is the growing population of enrollees which, of course, demands for more facilities including classrooms and more reference materials. To provide a conducive environment for learning, it is suggested that the local government will provide budget for the construction of facilities and acquisition of needed reference materials.

\section{ACKNOWLEDGEMENT}

The researchers extend their gratitude to the Department of Interior and Local Government (DILG) and the Aklan State University (ASU) administration for being the major counterparts in making this study possible.

\section{REFERENCES}

Citizen Satisfaction Index System Manual for Pilot Testing in Municipalities. Bureau of Local Government Supervision-Department of Interior and Local Government, Quezon City, 2018, Ch. 3 - 5.

"Republic Act No. 1414 - An Act To Create the Province of Aklan". Chan Robles Virtual Law Library. 25 April 1956. Archived from the original on 4 March 2016. Retrieved 15 July 2018.

Census of Population (2015). "Region VI (Western Visayas)". Total Population by Province, City, Municipality and Barangay. PSA. Retrieved 5 April 2018.

"Municipal: Lezo, Aklan". PSGC Interactive. Quezon City, Philippines: Philippine Statistics Authority. Retrieved 28 June 2018. 